\title{
Effect of wind speed on the size distribution of gel particles in the sea surface microlayer: insights from a wind-wave channel experiment
}

\author{
Cui-Ci Sun ${ }^{1,2,3}$, Martin Sperling ${ }^{1}$, and Anja Engel ${ }^{1}$ \\ ${ }^{1}$ GEOMAR Helmholtz Centre for Ocean Research Kiel, 24105 Kiel, Germany \\ ${ }^{2}$ State Key Laboratory of Tropical Oceanography, South China Sea Institute of Oceanology, Chinese Academy of Sciences, \\ 510301, Guangzhou, China \\ ${ }^{3}$ Daya Bay Marine Biology Research Station, Chinese Academy of Sciences, 518000, Shenzhen, China
}

Correspondence: Anja Engel (aengel@geomar.de)

Received: 11 October 2017 - Discussion started: 23 October 2017

Revised: 22 May 2018 - Accepted: 29 May 2018 - Published: 15 June 2018

\begin{abstract}
Gel particles, such as transparent exopolymer particles (TEP) and Coomassie stainable particles (CSP), are important organic components in the sea surface microlayer (SML). Here, we present results on the effect of different wind speeds on the accumulation and size distribution of TEP and CSP during a wind wave channel experiment in the Aeolotron. Total areas of TEP (TEP SML $_{\text {) }}$ and CSP $\left(\mathrm{CSP}_{\mathrm{SML}}\right)$ in the surface microlayer were exponentially related to wind speed. At wind speeds $<6 \mathrm{~m} \mathrm{~s}^{-1}$, accumulation of TEP SML $_{\text {and CSP }}$ SML occurred, decreasing at wind speeds of $>8 \mathrm{~m} \mathrm{~s}^{-1}$. Wind speeds $>8 \mathrm{~m} \mathrm{~s}^{-1}$ also significantly altered the size distribution of $\mathrm{TEP}_{\mathrm{SML}}$ in the $2-16 \mu \mathrm{m}$ size range towards smaller sizes. The response of the CSP $\mathrm{CML}_{\mathrm{SML}}$ size distribution to wind speed varied through time depending on the biogenic source of gels. Wind speeds $>8 \mathrm{~m} \mathrm{~s}^{-1}$ decreased the slope of $\mathrm{CSP}_{\mathrm{SML}}$ size distribution significantly in the absence of autotrophic growth. For the slopes of TEP and CSP size distribution in the bulk water, no significant difference was observed between high and low wind speeds. Changes in spectral slopes between high and low wind speed were higher for $\mathrm{TEP}_{\mathrm{SML}}$ than for $\mathrm{CSP}_{\mathrm{SML}}$, indicating that the impact of wind speed on size distribution of gel particles in the SML may be more pronounced for TEP than for CSP, and that $\mathrm{CSP}_{\mathrm{SML}}$ are less prone to aggregation during the low wind speeds. Addition of an E. huxleyi culture resulted in a higher contribution of submicron gels $(0.4-1 \mu \mathrm{m})$ in the SML at higher wind speed $\left(>6 \mathrm{~m} \mathrm{~s}^{-1}\right)$, indicating that phytoplankton growth may potentially support the emission of submicron gels with sea spray aerosol.
\end{abstract}

\section{Introduction}

Two kinds of gel particles have been widely studied in aquatic environments: transparent exopolymer particles (TEP), which include acidic polysaccharides, and Coomassie stainable particles (CSP), which are protein-containing particles and can serve as a N source for bacteria and other organisms (Alldredge et al., 1993; Long and Azam, 1996; Passow, 2002; Engel et al., 2004). A major source of TEP and CSP in the ocean are phyto- and bacterioplankton (Alldredge et al., 1993; Long and Azam, 1996; Stoderegger and Herndl, 1999). Previous studies highlighted the importance of gels for increasing gelatinous biofilm formation in the sea surface microlayer (SML) (Wurl and Holmes, 2008; Cunliffe et al., 2013) and mediating vertical organic matter transport, either up to the atmosphere or down to the deep ocean (AzetsuScott and Niven, 2005; Ebling and Landing, 2015; Guasco et al., 2014; Mari et al., 2017). In addition, it has been suggested that gels play an important role in air-sea exchange processes. Gel particles with a polysaccharide composition ejected by bubble bursting events may act as cloud condensation nuclei $(\mathrm{CCN})$ in low-level cloud regions (Leck and Bigg, 2005; Russell et al., 2010; Orellana et al., 2011). Also, proteinaceous gels and amino acids can be enriched in the SML and in sea spray aerosols (SSAs) (Kuznetsova et al., 2005). Since gel particles with fractal scaling provide a relatively large surface-to-volume ratio, they are assumed to act as barriers at the interface between air and sea, potentially reducing molecular diffusion rates (Engel and Galgani, 2016). Thus, the enrichment of organic matter, including gels, in the SML could modulate the air-sea gas exchange at low and inter- 
mediate winds (Calleja et al., 2009; Mesarchaki et al., 2015; Wurl et al., 2016; Engel and Galgani, 2016).

Particle-size distribution (PSD) is a trait description of gel particles that relates to many important processes. It has been demonstrated that marine heterotrophs feed on gel particles within specific size ranges (Mari and Kiorboe, 1996). Bacterial colonization of TEP varies as a function of size (Mari and Kiorboe, 1996; Passow, 2002). Thus, changes in size distribution of gel particles will likely alter food-web structure and dynamics in the ocean and SML.

Gel PSD and its variation with biogeochemical and physical processes generally reflect the information about coagulation, breakup and dissolution as well as on sources and sinks of gel particles, either moving upward into or sinking out of the SML. In addition, the abundance and size of gels in the SML and in subsurface waters may determine their potential fate as CCN in the atmosphere (Orellana et al., 2011).

Wind was determined as a principal force that controls accumulation of particulate material in the SML and as the most important variable controlling the air-sea exchange of gas and particles (Liu and Dickhut, 1998; UNESCO, 1985; Frew et al., 2004). The SML is expected to disrupt at higher wind speed, but the threshold wind speed for organic matter enrichment in general, and for specific components in particular, is largely unknown (Liss, 2005). Natural slicks often occur at low wind speeds $\left(<6 \mathrm{~m} \mathrm{~s}^{-1}\right)$ typically having wider area coverage for a longer time in coastal seas compared to the open ocean (Romano, 1996). Using different SML sampling methods, such as a Teflon plate, glass plate and Garret screen (Garrett and Duce, 1980), direct relationships between wind speed and SML thickness have been determined. However, the influence of wind on SML thickness is not clear; Liu and Dickhut (1998) observed a decrease with a wind speed of up to $5 \mathrm{~m} \mathrm{~s}^{-1}$, while Falkowska (1999) determined an increase up to a wind speed of $8 \mathrm{~m} \mathrm{~s}^{-1}$, beyond which the thickness of the SML began to decrease.

TEP enrichment in the SML has been described as inversely related to wind speed greater than $5-6 \mathrm{~m} \mathrm{~s}^{-1}$ (Wurl et al., 2009, 2011; Engel and Galgani, 2016). One explanation for this is that at higher wind speed, aggregation of solid particles with TEP results in aggregates becoming negatively buoyant and sinking out of the SML. For proteinaceous gels, Engel and Galgani (2016) observed that their enrichment was not inversely related to wind speed. However, an inverse relationship between the slope of the CSP size distribution in the SML and wind speed was observed, indicating larger CSP in the SML at low wind speed. In addition, the dynamics of gel particles in the SML were also affected by other mechanisms that depend on the wind and wave conditions. It is proposed that gel particle formation within the SML is supported by bubble scavenging of dissolved organic matter (DOM) in the upper water column (Wurl et al., 2011) because more TEP precursors are lifted up the water column. Moreover, compression and dilatation of the SML due to capillary waves may increase the rate of polymer collision, subsequently facilitating gel aggregation (Carlson, 1983).

Wurl et al. (2011) provided a conceptual model for the production and fate of TEP in surface waters and the underlying controlling mechanisms. However, due to the lack of observational data, we do not understand how the size distribution of marine gel particles in the SML varies as a function of wind speed and wave action well. Knowledge of the characteristics of gel particles such as abundance, total area, and size distribution in the SML and how they relate to wind speed may improve our understanding of marine primary organic aerosol emission-cloud feedback processes and may help to accurately estimate trace gas fluxes from the ocean to the atmosphere. Here, we assess the dynamics of size distribution of marine gel particles, i.e., TEP and CSP, in the SML in response to different wind speeds.

\section{Methods}

\subsection{Experimental setup}

Effects of different wind speeds on the size distribution of organic gel particles in the SML were studied during the Aeolotron experiment from 3 to 28 November 2014. A total of $22000 \mathrm{~L}$ of North Atlantic seawater was pumped and collected by the research vessel Poseidon, including $\sim 14000 \mathrm{~L}$ collected at $55 \mathrm{~m}$ of depth at $64^{\circ} 4.90^{\prime} \mathrm{N}, 8^{\circ} 2.03^{\prime} \mathrm{E}$ and $\sim 8000 \mathrm{~L}$ collected on 22 September 2014 at $5 \mathrm{~m}$ of depth near the island of Sylt in the German Bight, North Sea. The water was pumped into a clean ("food save") road tanker and unloaded at the wind-wave facility Aeolotron the following day and stored in a dark and cool $\left(\sim 10^{\circ} \mathrm{C}\right)$ place until the start of the experiment. It took 41 days from sampling to start the experiment. The Aeolotron (Heidelberg, Germany) is a large-scale annular wind-wave facility with a total height of $2.4 \mathrm{~m}$, and an outer diameter of $10 \mathrm{~m}$. The wind speed inside the channel was measured using a Pitot tube and anemometer. A more detailed description of the facility is given by Nagel et al. (2015). The friction velocity $U^{\star}$ was determined and converted into the value $U_{10}$ as described in Maximilian Bopp and Bernd Jähne (unpublished, 2014), with $U_{10}$ being the equivalent wind speed at $10 \mathrm{~m}$ height above the ocean.

The experiment started on 3 November (day 1). Seven experiments were conducted on days $2,4,9,11,15,22$ and 24 , with a stepwise increase in wind speeds $\left(U_{10}\right)$, ranging from 1.37 to $18.7 \mathrm{~m} \mathrm{~s}^{-1}$ as shown in Table 1 . At some conditions, data of water velocity were absent; hence no values for $U_{10}$ could be obtained. On experimental days, wind started at about 08:00 CET in the morning and ended at about 20:30 CET in the evening. The actual wind speeds over the seven experiment days varied a little, but all followed the same strategy of setting shown in the conceptual Fig. 1. Seawater temperature over the course of the experiment was about $21 \pm 1{ }^{\circ} \mathrm{C}$. A series of manipulations was carried out 
Table 1. Wind speed settings as applied during strategy I of the Aeolotron experiment; "NaN": no values for $U_{10}$.

\begin{tabular}{l|rrrrrr}
\hline Day & \multicolumn{5}{|c}{ Wind velocity $U_{10}\left(\mathrm{~m} \mathrm{~s}^{-1}\right)$} \\
\hline 2 & NaN & NaN & 3.98 & 5.38 & 11.1 & 17.9 \\
4 & 2.09 & 3.44 & 4.31 & 8.31 & 14.2 & \\
9 & 1.54 & 2.40 & 4.07 & 5.29 & 11.1 & \\
11 & 1.66 & 2.89 & 3.93 & 8.03 & 14.0 & NaN \\
15 & 2.58 & 4.99 & 6.42 & 11.1 & 18.1 & \\
22 & 1.37 & 1.37 & 4.53 & 6.1 & 11.3 & 18.7 \\
24 & 1.44 & 2.65 & 4.27 & 5.38 & 11.4 & 18.1 \\
\hline
\end{tabular}

during the experiment and are described in more detail in the Supplement. On day 20, a seed culture of Emiliania huxleyi (cell density: $4.6 \times 10^{5}$ cell $\mathrm{mL}^{-1}$ ) was added, followed by a biogenic SML from a previous experiment on day 21 . A pair of SML and bulk water samples was collected at the end of each wind condition except for days 2 and 4, when the bulk water was collected at the start (morning) and the end (evening) of the experiment. Developments of TEP and CSP in the SML and the bulk water in the course of the Aeolotron study are shown in the Supplement (Fig. S1). Compared to the significant changes of gel particle concentration with wind speed observed in the SML, gel concentration changes with wind speed in the bulk water were much smaller. Thus, overall gel concentration in the bulk water was not sensitive to wind speed changes.

\subsection{Sampling}

SML samples were collected with a glass plate sampler, made of borosilicate glass with dimensions of $500 \mathrm{~mm}$ (length) $\times 250 \mathrm{~mm}$ (width) $\times 5 \mathrm{~mm}$ (thickness) and with an effective surface area of $2000 \mathrm{~cm}^{2}$ (considering both sides). For each sample, the glass plate was inserted into the water perpendicular to the surface and withdrawn at a rate of $\sim 20 \mathrm{~cm} \mathrm{~s}^{-1}$. The sample, retained on the glass because of surface tension, was removed by a Teflon wiper. The water from all dips pooled into one sample. Sample volumes were $210-355 \mathrm{~mL}$ for the SML and $800-1000 \mathrm{~mL}$ for bulk water. Samples were collected into acid-cleaned $(\mathrm{HCl}, 10 \%)$ and Milli-Q-washed glass bottles. Prior to sampling, both glass plate and wiper were rinsed with Milli-Q water and intensively rinsed with Aeolotron water in order to minimize their contamination with alien material. The first milliliters of the SML sample were used to rinse the bottles and then discarded. The bulk water was sampled from the outlet at the middle-lower part of the Aeolotron and collected into acidcleaned $(\mathrm{HCl}, 10 \%)$ and Milli-Q-washed glass bottles.

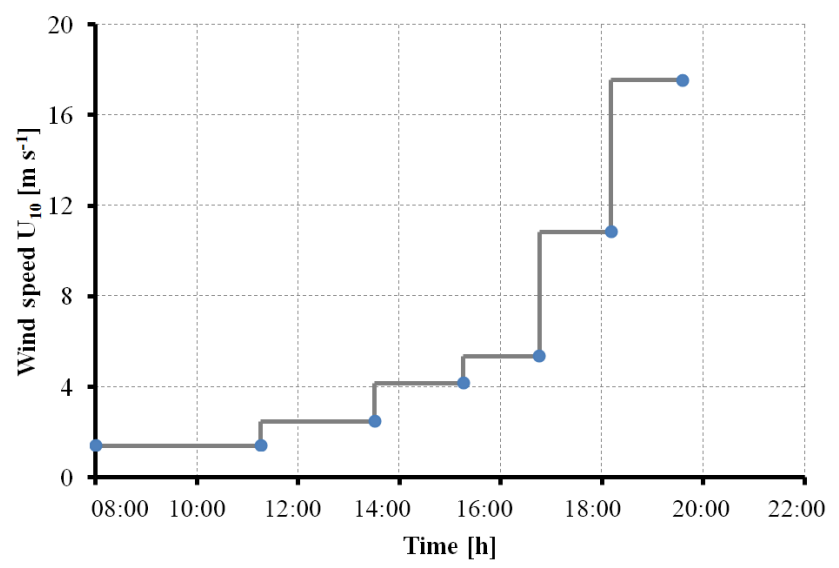

Figure 1. Schematic wind speed $\left(U_{10}\right)$ increase as applied during strategy I for experiments conducted in the Aeolotron.

\subsection{Analytical methods}

Total area, particle numbers and equivalent spherical diameter $\left(d_{\mathrm{p}}\right)$ of gel particles were determined by microscopy following Engel (2009). For TEP and CSP, 5 to $30 \mathrm{~mL}$ were gently filtered $(<150 \mathrm{mbar})$ onto $25 \mathrm{~mm}$ Nuclepore membrane filters $(0.4 \mu \mathrm{m}$ pore size, Whatman Ltd.), stained with $1 \mathrm{~mL}$ Alcian Blue solution for polysaccharide gels and $0.5 \mathrm{~mL}$ Coomassie Brilliant Blue G (CBBG) working solution for proteinaceous gels. The excessive dye was removed by rinsing the filter with Milli-Q water. Blank filters for gel particles were prepared using Milli-Q water. Filters were transferred onto Cytoclear@ slides and stored at $-20^{\circ} \mathrm{C}$ until microscopic analysis. Each treatment had two duplicates. For each filter, about 30 images were randomly taken at $\times 200 \mathrm{mag}$ nification with a light microscope (Zeiss Axio Scope A.1). Image-analysis software (Image J, US National Institutes of Health) was used to analyze particle numbers and area. The total particle abundance and total area were determined from a minimum particle size of $0.4 \mu \mathrm{m}$ equivalent spherical diameter (ESD). The submicron gel particles during this study covered a range of $0.4-1 \mu \mathrm{m}$.

The size-frequency distribution of TEP and CSP gels was described by

$\frac{\mathrm{d} N}{\mathrm{~d}\left(d_{\mathrm{p}}\right)}=k d_{\mathrm{p}}^{\delta}$,

where $\mathrm{d} N$ is the number of particles per unit water volume in the size range $d_{\mathrm{p}}$ to $\left(d_{\mathrm{p}}+\mathrm{d}\left(d_{\mathrm{p}}\right)\right)$ (Mari and Kiorboe, 1996). The factor $k$ is a constant that depends on the total number of particles per volume, and $\delta(\delta<0)$ describes the spectral slope of the size distribution. The less negative is $\delta$, the greater is the fraction of larger gels. The process of collision of particle in shear is typically important for particles larger than a few micrometers in diameter and less important than Brownian motion for particles in the submicron size range (McCave, 1984); therefore both $\delta$ and $k$ were derived 
from regressions of $\log \left[\mathrm{d} N / \mathrm{d}\left(d_{\mathrm{p}}\right)\right]$ versus $\log \left[d_{\mathrm{p}}\right]$ over the size range 2-16 $\mu \mathrm{m}$ ESD.

On day 11, samples taken at a wind speed of 1.66 and $2.89 \mathrm{~m} \mathrm{~s}^{-1}$ were contaminated and therefore removed from data analysis and discussion.

\subsection{Data analysis}

Results from the SML samples were compared to those of bulk water and expressed as enrichment factors (EFs), defined as

$\mathrm{EF}=(C)_{\mathrm{SML}} /(C)_{\mathrm{Bulk}}$,

where $(C)$ is the concentration of a given parameter in the SML or bulk water (GESAMP, 1995). Enrichment of a component is generally indicated by $\mathrm{EF}>1$, depletion by $\mathrm{EF}<1$. Considering the measurement uncertainty of gel particles using the microscopic method within $10 \%$, EF values $>1.1$ thus represent significant enrichment of gel particles in the SML, while $\mathrm{EF}<0.9$ is determined to be a depletion.

Nonparametric statistics (two-sample KolmogorovSmirnov test) was performed to compare differences of slope of gel particle size distribution between low and moderate wind speeds $\left(<8 \mathrm{~m} \mathrm{~s}^{-1}\right)$ and high wind speeds $\left(>8 \mathrm{~m} \mathrm{~s}^{-1}\right)$. In addition, statistical significance of changes with respect to the slope of gel particle size distribution after adding the seed culture of E. huxleyi and the biogenic SML water from a previous experiment was determined with a two-sample Kolmogorov-Smirnov test on non-normalized anomalies given the data being normally distributed. Average values are given by the statistical mean and its standard deviation (SD). Statistical significance was accepted for $p<0.05$. Calculations and statistical tests were conducted using Microsoft Office Excel 2010 and Origin 9.0 (OriginLab Corporation, USA) software.

\section{Results}

\subsection{Biological variations during the Aeolotron experiment}

Temporal changes in hetero- and autotrophic plankton and neuston abundance and in organic matter during the experiment will be described in more detail elsewhere (Engel et al., 2018) and are summarized here only briefly. Heterotrophic microorganisms dominated cell abundance and biomass in the tank during the whole study. Two peaks of bacterial abundance in the SML occurred on days 4 and 11. Primary production was low during the whole experiment. Chlorophyll $a$ (chl a) concentrations were not detectable until days 2021 , i.e., after the addition of the E. huxleyi culture and the SML water from a previous phytoplankton bloom experiment. Chl $a$ concentration clearly increased after day 23 .

\subsection{TEP and CSP abundance and total area variations with respect to wind speeds}

Before the onset of the wind experiments, the water surface was flat without visible surface movement. As the wind speed increased, the first capillary waves became visible and started breaking above about $U_{10}=6 \mathrm{~m} \mathrm{~s}^{-1}$ (e.g., $U_{10}=6.1 \mathrm{~m} \mathrm{~s}^{-1}$ on day 22). At this wind speed, abundance of TEP SML decreased, except for days 15 and 11, when abundance of $\mathrm{TEP}_{\text {SML }}$ remained relatively stable or even increased slightly at high wind speed (Fig. 2). Similar to TEP ${ }_{S M L}$, abundance and total area of $\mathrm{CSP}_{\mathrm{SML}}$ decreased with increasing wind speed, excluding days 11 and 2 (Fig. 3). Exponential declines of total area $\mathrm{TEP}_{\mathrm{SML}}$ and $\mathrm{CSP}_{\mathrm{SML}}$ with increasing wind speed were observed, except for $\mathrm{TEP}_{\mathrm{SML}}$ area on days 11 and 15, and CSPSML area on day 15; a measure of the goodness of exponential fit is the coefficient of determination (COD), denoted as $r^{2}$ yielding $r_{\mathrm{CSP}-\text { Total area }}^{2}=0.73 \pm 0.20$, $n=6$ and $r_{\text {TEP-Total area }}^{2}=0.87 \pm 0.19, n=5$. In contrast to total area, only three out of seven observations for abundance of TEPSML and two out of seven for abundance of $\mathrm{CSP}_{\text {SML }}$ were exponentially related to wind speed. Thus, the relationship between abundance of gel particles in the SML and wind speeds could not be well described by an exponential function. Nevertheless, the reduction of gel particle abundance and area in the SML indicated a clear removal from the SML with increasing wind speed. Enrichment of gel particles, with $\mathrm{EF}>1.2$, for both abundance and total area were generally found at a wind speed of $2-6 \mathrm{~m} \mathrm{~s}^{-1}$ (Table 2), except for day 15 on which high CSP enrichment in the SML $\left(\mathrm{EF}_{\text {Abundance }}=4.10\right.$ and $\left.\mathrm{EF}_{\text {Total area }}=3.20\right)$ was observed at a wind speed of $18 \mathrm{~m} \mathrm{~s}^{-1}$. Although the median of EFs was significantly lower at wind speed $>6 \mathrm{~m} \mathrm{~s}^{-1}$ than at a wind speed of $2-6 \mathrm{~m} \mathrm{~s}^{-1}(p<0.05$; two-sample Kolmogorov-Smirnov test) (Table 2), gel particles were not always depleted in the SML at high wind speeds. Enrichment of both CSP and TEP at low wind speed was higher for total area than for abundance (Table 2), suggesting selective enrichment of larger gel particles in the SML.

\subsection{TEP and CSP size distributions related to wind speeds}

The power-law relation fitted the gel particle size distribution $\left(d_{\mathrm{p}}: 2-16 \mu \mathrm{m}\right)$ very well for both $\mathrm{CSP}_{\mathrm{SML}}$ and TEP $\mathrm{SML}_{\mathrm{SM}}$ under different wind speed conditions (mean of $r^{2}=0.95$ ) (Figs. 4 and 5; slope $(\delta)$ data in the SML are given in the Supplement). The slopes of size distributions for TEP SML $_{2}$ ranged from -2.93 to -1.32 (median of $-2.17, n=16$ ) at low and moderate wind speeds $\left(<8 \mathrm{~m} \mathrm{~s}^{-1}\right)$ and were significantly higher than those at high speeds $\left(>8 \mathrm{~m} \mathrm{~s}^{-1}\right)$ ranging from -4.05 to -2.39 (median of $-3.11, n=9)(p<0.05$; two-sample Kolmogorov-Smirnov test), excluding samples in the SML collected from days 15 and 11 . Moreover, $8 \mathrm{~m} \mathrm{~s}^{-1}$ was the threshold below which an obvious increase in maxi- 

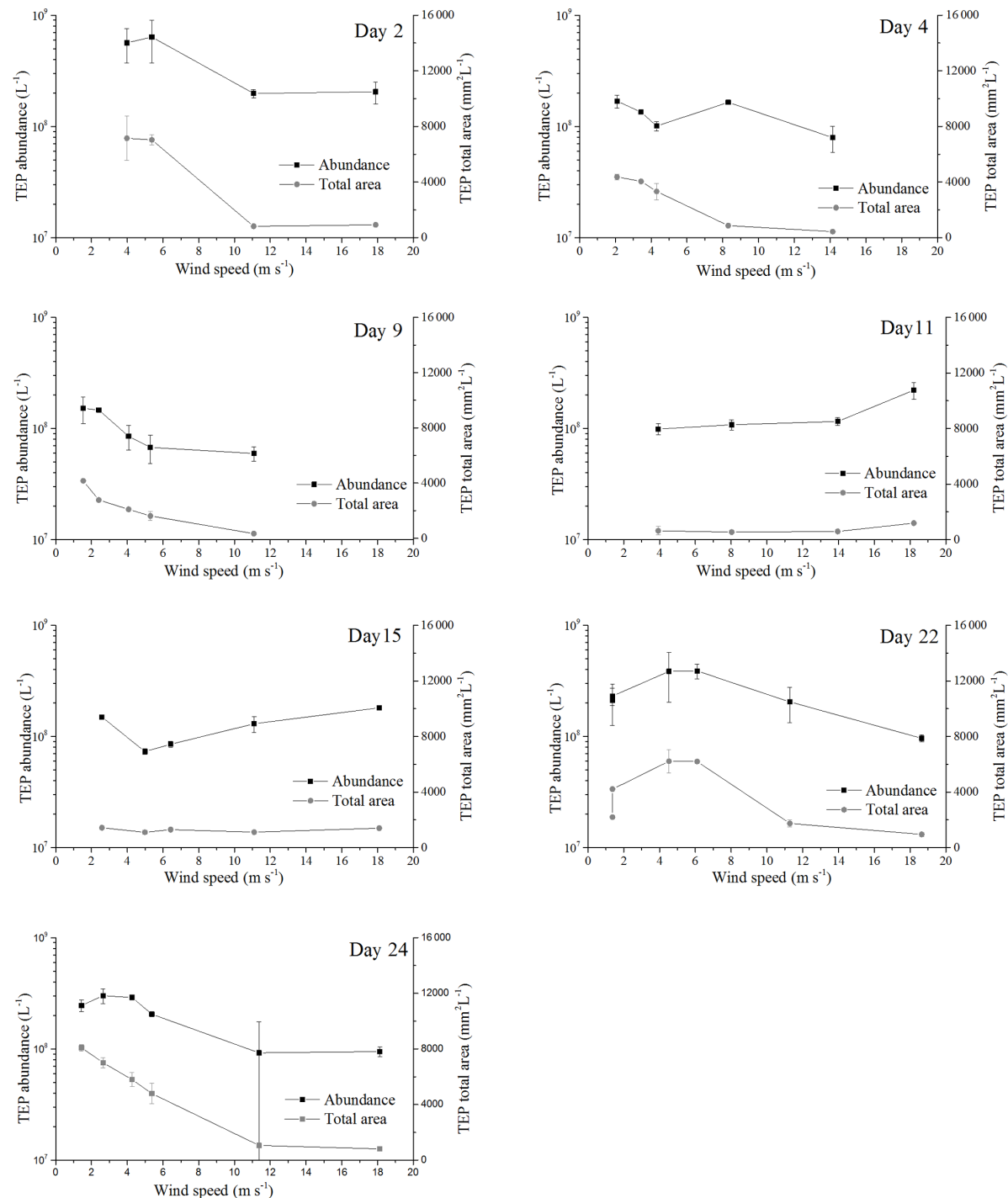

Figure 2. Response of abundance and total area for $\mathrm{TEP}_{\mathrm{SML}}$ to increasing wind speeds; the error bars indicate $\pm 1 \mathrm{SD}$.

mal gel particle size in the SML was found except for day 15. The response of $\mathrm{CSP}_{\mathrm{SML}}$ slopes to the wind speed varied over time of the experiment. From days 2 to 11, the slopes of $\mathrm{CSP}_{\mathrm{SML}}$ were significantly lower at high wind speed $\left(>8 \mathrm{~m} \mathrm{~s}^{-1}\right)(-3.78$ to -3.05 , median of $3.28, n=8)$ than at $<8 \mathrm{~m} \mathrm{~s}^{-1}$ ( -3.25 to -2.41 , median of $\left.-2.63, n=12\right)$ ( $p<0.001$; two-sample Kolmogorov-Smirnov test). However, during the second part of the experiment, when a seed culture of E. huxleyi was added on day 20 , followed by a biogenic SML from a previous experiment on day 21, no significant difference of $\mathrm{CSP}_{\mathrm{SML}}$ size distribution was observed between high and low wind speeds ( $p=0.51$, twosample Kolmogorov-Smirnov test), and the negative effect of increasing wind on the maximum size for CSP $\mathrm{SML}_{\mathrm{SM}}$ was less obvious (Fig. 6). In addition, the $\delta$ values for $\mathrm{CSP}_{\mathrm{SML}}$

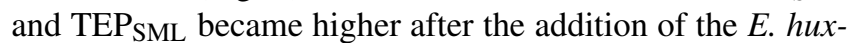
leyi culture. The average slope increased from -2.94 before to -2.37 for $\mathrm{CSP}_{\mathrm{SML}}$ and from -2.79 before to -2.16 for TEP $_{\text {SML }}$ (Fig. 7).

Size distribution of gel particles $\left(d_{\mathrm{p}}: 2-16 \mu \mathrm{m}\right)$ in the bulk water also followed the power-law relationship of Eq. (1) (mean of $r^{2}=0.99$ ), with $\delta$ varying between -3.48 and -1.94 (mean value: -2.56 , SD: 0.49) for TEP Bulk $_{\text {and be- }}$ tween -3.43 and -2.01 (mean value: -2.50 , SD: 0.42 ) for $\mathrm{CSP}_{\text {Bulk}}$. For the slopes of size distribution in the bulk water, no significant difference was observed between high and low wind speeds. However, as observed for the SML, the $\delta$ values of both TEP and CSP in the bulk water were higher after adding the seed culture of $E$. huxleyi on day 20 and a biogenic SML from a previous experiment on day 21 (Fig. 7) ( $p<0.05$, two-sample Kolmogorov-Smirnov test), i.e., the average slope of $\mathrm{CSP}_{\mathrm{Bulk}}$ with a size of $2-16 \mu \mathrm{m}$ was -2.84 before and -2.15 after addition of the $E$. huxleyi culture. 

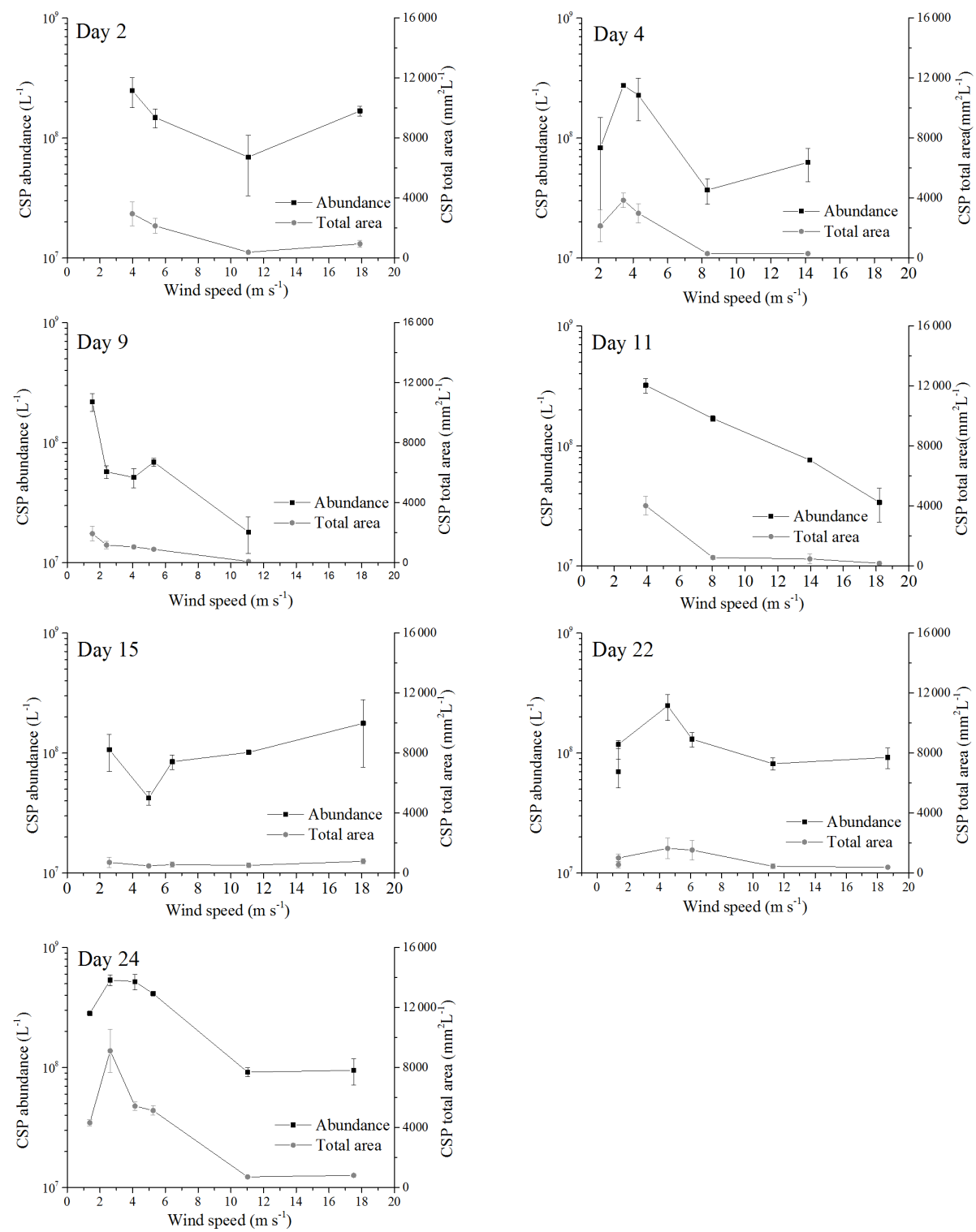

Figure 3. Response of abundance and total area for $\mathrm{CSP}_{\mathrm{SML}}$ to increasing wind speeds; the error bars indicate \pm 1 SD.

The abundance of submicron gel particles $(0.4-1 \mu \mathrm{m})$ in the SML was analyzed at low wind and high wind (Fig. S2). The results showed that the fraction of submicron gel particles became larger at high speed $\left(>6.1 \mathrm{~m} \mathrm{~s}^{-1}\right)$ during the period after addition of $E$. huxleyi followed by a biogenic SML from a previous experiment $\left(p=0.003\right.$ for TEP $\mathrm{TSL}_{\mathrm{SML}}, p=$ 0.02 for CSP $_{\text {SML }}$, two-sample Kolmogorov-Smirnov test). The median abundance fraction of submicron gel increased from $33.7 \%$ at low wind speed to $43.0 \%$ at high wind speed for $\mathrm{TEP}_{\mathrm{SML}}$ and from 38.5 to $46.0 \%$ for $\mathrm{CSP}_{\mathrm{SML}}$. There was no enhancement found in submicron fraction at high wind speed before the addition of $E$. huxleyi, with the exception of day 11 when the fraction of submicron TEPSML increased from $37.7 \%$ at $3.93 \mathrm{~m} \mathrm{~s}^{-1}$ to $51.4 \%$ at $18.2 \mathrm{~m} \mathrm{~s}^{-1}$.

\section{Discussion}

\subsection{TEP and CSP in SML related to wind speed}

The observed differences in concentration, enrichment factor and PSD in response to changes in wind speed revealed that wind speed was an important factor controlling the accumulation of gel particles in the SML during the Aeolotron experiment. Similar results were observed during previous studies, which showed that TEP and particulate organic matter concentrations in the SML were negatively related to wind speed (Wurl et al., 2011; Liu and Dickhut, 1998). Initial advection generated at wind speeds of $2-3 \mathrm{~m} \mathrm{~s}^{-1}$ maintain or enhance enrichments by increasing fluxes of potential microlayer materials to surfaces (Van Vleet and Williams, 1983). As wind 

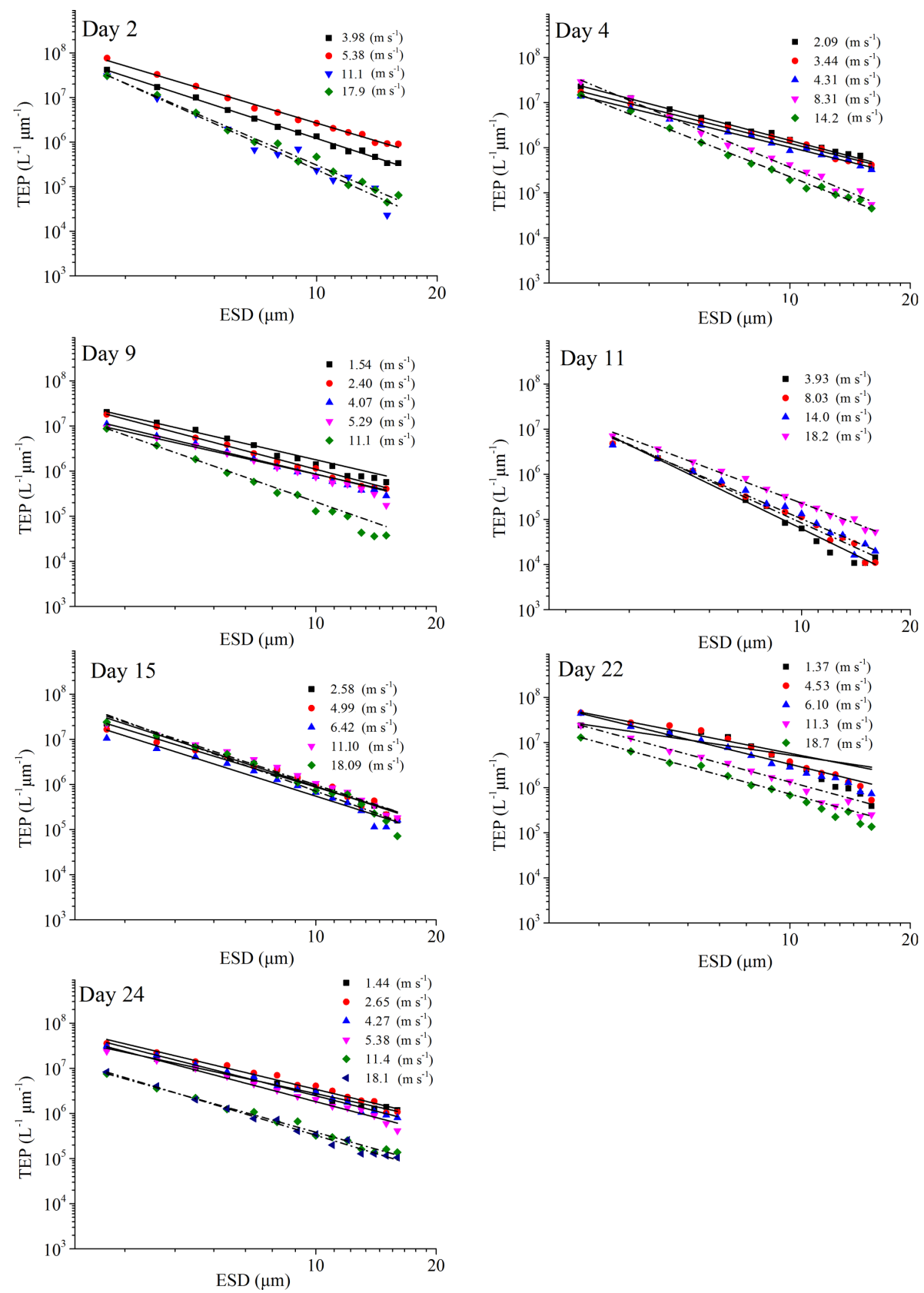

Figure 4. PSD of TEPSML at different wind speeds (linear regressions of $\log \left(\mathrm{d} N / \mathrm{d}\left(d_{\mathrm{p}}\right)\right)$ vs. $\log \left(d_{\mathrm{p}}\right)$ was fitted to particles in the size range of 2-16 $\mu \mathrm{m}$ ESD, with wind speeds $<8 \mathrm{~m} \mathrm{~s}^{-1}$ (solid line) and wind speeds $>8 \mathrm{~m} \mathrm{~s}^{-1}$ (dash and dot).

speed increases further $\left(4-6 \mathrm{~m} \mathrm{~s}^{-1}\right)$, microscale wave breaking is likely to increase the turbulence in the top surface layer, but it does not cause homogenous mixing (Melville, 1996). The contribution of the fraction of submicron gel particles increased when wind speed was above $6 \mathrm{~m} \mathrm{~s}^{-1}$, but the threshold of significant changing PSD in the SML was a wind speed of $8 \mathrm{~m} \mathrm{~s}^{-1}$. Thus, there is an inharmonic effect of wind speeds on the submicron fraction and PSD. For higher wind speeds of $8 \mathrm{~m} \mathrm{~s}^{-1}$ and above, the enhancement of shear and of kinetic energy dissipation by the release of momentum from the wave breaking (Donelan, 2013) was sufficiently energetic to bring about surface disruption and could result in more breakup of gel aggregates and changing PSD of gel particles. Our results on the impact of wind speed on gel particle PSD corroborates earlier findings of Mari and Robert (2008). Aggregation processes are primarily driven by collision rates among particles that depend on particle concentration and turbulent shear (Ellis et al., 2004; McCave, 1984; Mari and Robert, 2008). It has been suggested that TEP volume concentration increases continuously under the low turbulence 

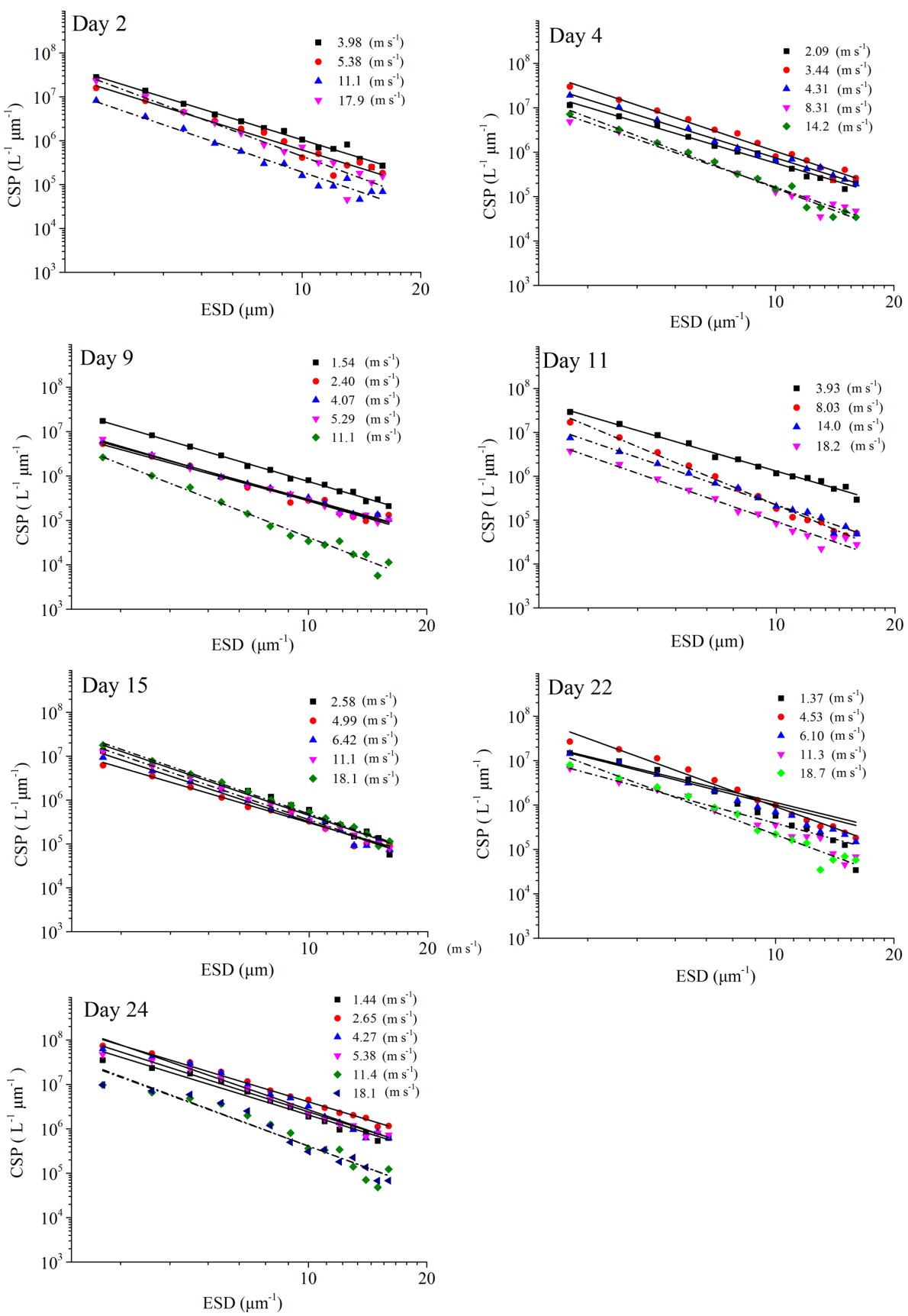

Figure 5. PSD of CSPSML at different wind speeds (linear regressions of $\log \left(\mathrm{d} N / \mathrm{d}\left(d_{\mathrm{p}}\right)\right)$ vs. $\log \left(d_{\mathrm{p}}\right)$ was fitted to particles in the size range of $2-16 \mu \mathrm{m}$ ESD, with wind speeds $<8 \mathrm{~m} \mathrm{~s}^{-1}$ (solid line) and wind speeds $>8 \mathrm{~m} \mathrm{~s}^{-1}$ (dash and dot)).

intensity by promoting the formation of TEP, but that TEP volume concentration and the fraction of large TEP are reduced at stronger shear (Mari and Robert, 2008). Thus, the effect of wind shear on gel aggregation is double-edged, and large aggregates may be broken apart when the turbulence intensity increases. Our study suggests that high wind speed leads to a breakup of larger gel particles, enhancing the fraction of submicron gels in the SML.
The results of this study indicate that the decrease in to-

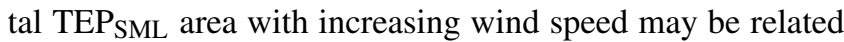
to turbulent kinetic energy dissipation $\varepsilon\left(\mathrm{cm}^{2} \mathrm{~s}^{-3}\right)$. The relationship between gel concentration and turbulence has been reported to be of an exponential form: $e^{(\varepsilon 1 / 2)}$ (Ruiz and Izquierdo, 1997). Therefore, increasing kinetic energy dissipation, which is a linear combination of wind speed and wave and buoyancy forcing within the mixed layer (Belcher et al., 2012), likely induces an exponential decrease in the 
Table 2. Enrichment factors (EFs) for gel particle abundance and total area in the SML at different wind speeds; $\left(\mathrm{EF}_{\mathrm{Total}}\right.$ area $>\mathrm{EF}_{\mathrm{Abundance}}$ are marked bold.)

\begin{tabular}{|c|c|c|c|c|c|}
\hline \multirow{2}{*}{$\begin{array}{l}\text { Experiment } \\
\text { day }\end{array}$} & \multirow{2}{*}{$\begin{array}{l}\text { Wind speed } \\
\qquad\left(\mathrm{ms}^{-1}\right)\end{array}$} & \multicolumn{2}{|c|}{ TEP } & \multicolumn{2}{|c|}{ CSP } \\
\hline & & $\mathrm{EF}_{\text {Abundance }}$ & $\mathrm{EF}_{\text {Total area }}$ & $\mathrm{EF}_{\text {Abundance }}$ & $\mathrm{EF}_{\text {Total area }}$ \\
\hline \multirow[t]{2}{*}{2} & $\mathrm{NaN}\left(<4 \mathrm{~ms}^{-1}\right)$ & 2.24 & 7.40 & 41.43 & 113.98 \\
\hline & 17.9 & 1.80 & 1.71 & 8.21 & 12.27 \\
\hline 4 & 2.09 & 0.97 & 5.71 & 3.52 & 26.81 \\
\hline \multirow[t]{4}{*}{9} & 1.54 & 3.34 & 16.16 & nd & nd \\
\hline & 2.40 & 4.80 & 12.76 & 1.84 & 7.08 \\
\hline & 5.29 & 1.44 & 5.40 & 1.20 & 2.78 \\
\hline & 11.1 & 1.08 & 1.07 & 0.74 & 0.72 \\
\hline \multirow[t]{2}{*}{11} & 3.93 & 0.91 & 1.16 & 13.46 & 31.16 \\
\hline & 18.2 & 1.63 & 1.53 & 1.11 & 1.12 \\
\hline \multirow[t]{5}{*}{15} & 2.58 & 1.06 & 1.13 & 1.28 & 1.03 \\
\hline & 4.99 & 0.48 & 0.77 & 0.47 & 1.08 \\
\hline & 6.42 & 0.68 & 0.95 & 1.39 & 2.02 \\
\hline & 11.1 & 0.77 & 0.70 & 2.14 & 1.50 \\
\hline & 18.1 & 1.28 & 1.02 & 4.10 & 3.20 \\
\hline \multirow[t]{5}{*}{22} & 1.37 & 3.06 & 4.38 & 1.14 & 2.41 \\
\hline & 4.53 & 3.06 & 5.04 & 5.46 & 4.54 \\
\hline & 6.10 & 2.94 & 4.78 & 1.34 & 2.23 \\
\hline & 11.3 & 0.61 & 1.02 & 1.07 & 1.02 \\
\hline & 18.7 & 0.44 & 0.58 & 1.41 & 0.85 \\
\hline \multirow[t]{5}{*}{24} & 1.44 & 4.68 & 8.21 & 1.82 & 3.93 \\
\hline & 4.27 & 6.97 & 6.06 & 5.94 & 6.82 \\
\hline & 5.38 & 6.42 & 5.19 & 2.44 & 4.05 \\
\hline & 11.4 & 2.38 & 1.23 & 0.72 & 0.66 \\
\hline & 18.1 & 1.74 & 0.81 & 0.65 & 0.69 \\
\hline Median of EFs & $<6 \mathrm{~ms}^{-1}$ & 3.06 & 7.81 & 6.48 & 19.22 \\
\hline Median of EFs & $>6 \mathrm{~ms}^{-1}$ & 1.28 & 1.53 & 2.14 & 2.23 \\
\hline
\end{tabular}

total area of gels in the SML. However, an exponential relationship was not observed between abundance of gel particles and wind speed in this study. A likely explanation is that the abundance of gel particles was influenced not only by turbulence levels but also by bubble scavenging and bursting at higher speed. In particular small particles that contribute more to total abundance than to total area can accumulate in the SML due to bubble scavenging at high wind speed. This may explain why changes in gel particle abundance did not fit well to an exponential function with wind speed in our study.

According to our results, the average slopes showed about $41.2 \%$ changes for TEP $_{\text {SML }}$ at a speed $>8 \mathrm{~m} \mathrm{~s}^{-1}$ compared to low wind speed, but only $23.8 \%$ for $\mathrm{CSP}_{\mathrm{SML}}$. The change in slope of size distribution between high and low wind speeds was thus higher for TEP $\mathrm{TML}_{\mathrm{SM}}$ than $\mathrm{CSP}_{\mathrm{SML}}$. In addition, after adding the E. huxleyi seed culture, no influence of wind speed on slopes of CSP $_{\text {SML }}(2-16 \mu \mathrm{m})$ was detected. These results indicated that the influence of wind speed on size distribution of gel particles may be more pronounced for $\mathrm{TEP}_{\mathrm{SML}}$ than for $\mathrm{CSP}_{\mathrm{SML}}$ (Prieto et al., 2002; Engel and Galgani, 2016).

\subsection{Implication of gel particles in the SML}

At a lower wind speed, EFs of gel particles in the SML were higher for total area than for abundance. This suggests that large gel particles became selectively enriched in the SML and, due to their larger surface area, may act as a cover sheet, potentially impacting processes across the air-sea interface at low wind speeds. Based on the data from the Aeolotron experiment, a schematic diagram on interactions between physical dynamics and gel particle coverage in the SML is proposed (Fig. 8): the enrichment of TEP and CSP in the SML existed until wind speed reached $6 \mathrm{~m} \mathrm{~s}^{-1}$, with strong enrichment at about $2-4 \mathrm{~m} \mathrm{~s}^{-1}$, at which slick streaks and bands were observed visually. Although surface tension measurements were not made, values for the mean square slope, a measurement of surface roughness, were 2 or 3 orders of magnitude higher at wind speeds $>6 \mathrm{~m} \mathrm{~s}^{-1}$ than at wind speeds $<6 \mathrm{~m} \mathrm{~s}^{-1}$ (Maximilian Bopp and Bernd Jähne, personal communication, 2016). At a wind speed of $8 \mathrm{~m} \mathrm{~s}^{-1}$ the sea surface became rougher and wave breaking started. In consequence, the SML started to mix with the subsurface water, leading to a more homogeneous distribution of mat- 

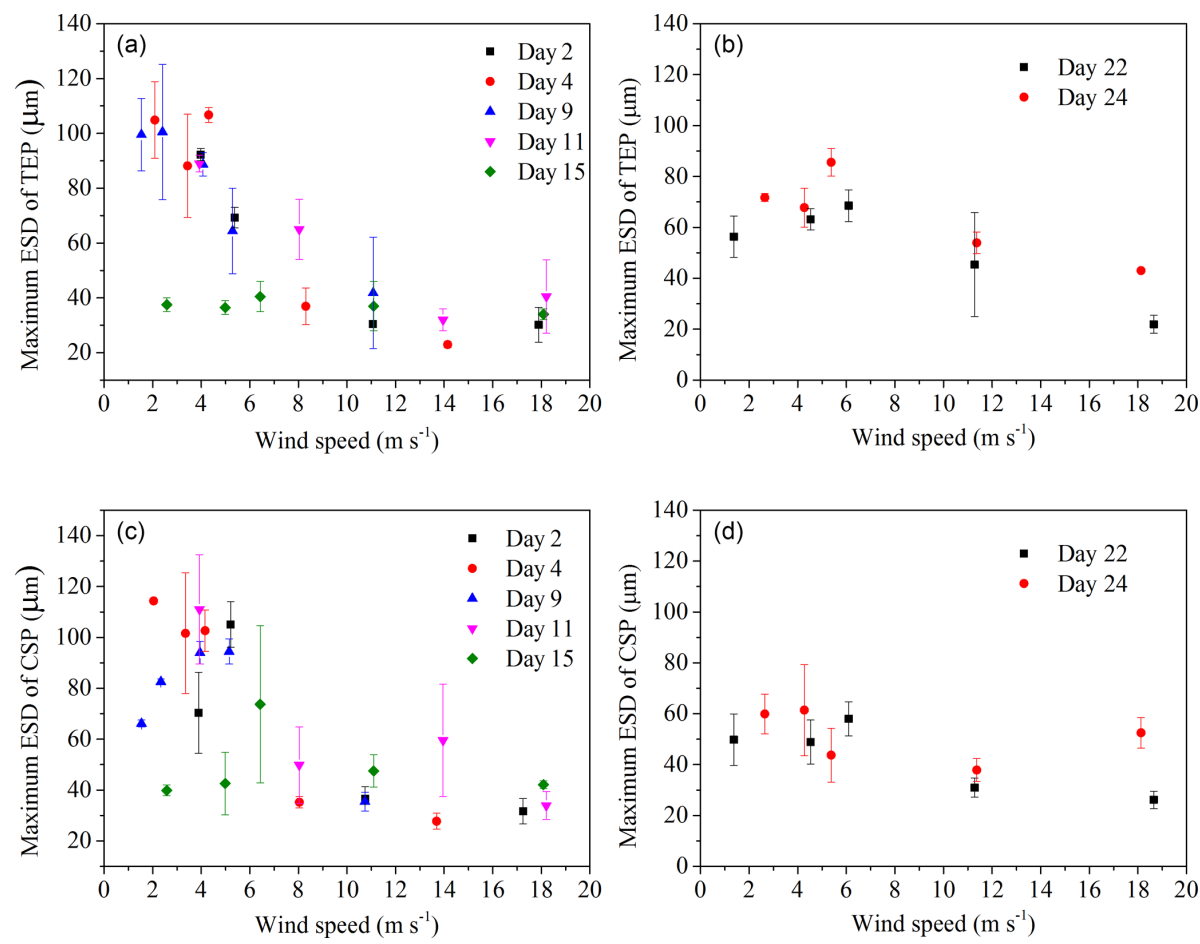

Figure 6. Maximum size (ESD) of gel particles in the SML; (a) and (c) before addition of E. huxleyi; (b) and (d) after addition of E. huxleyi.

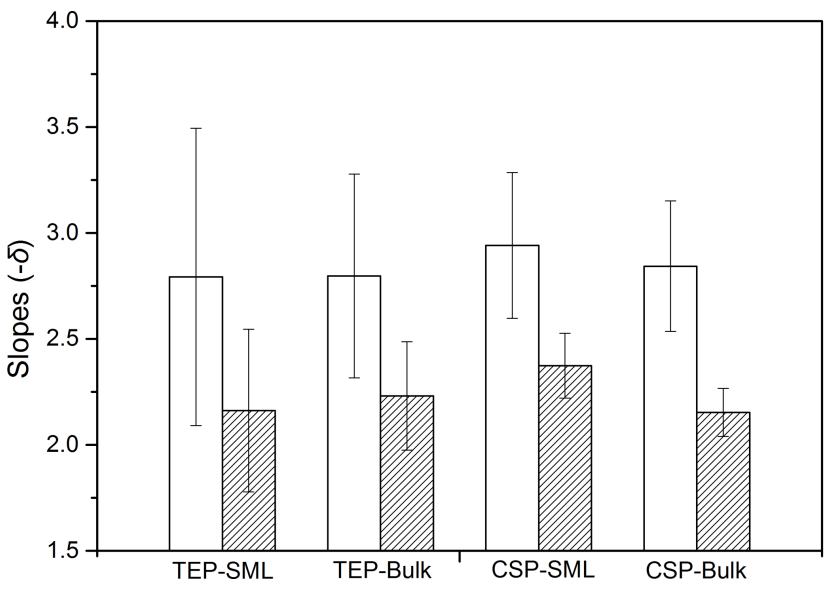

Figure 7. Average slopes of gel particles in the bulk water and SML. Open bars: before addition of $E$. huxleyi; hatched bars: after addition of E. huxleyi; error bars indicate $\pm 1 \mathrm{SD}$.

ter in the surface water column and a potential role of gel particles in gas exchange would be reduced.

Under conditions of high wind and wave breaking, submicron gels can be aerosolized with sea spray (Gantt et al., 2011). For the ocean, gel particle emission in aerosols has recently been discussed with respect to cloud formation, precipitation, the hydrological cycle and climate (Knopf et al., 2011; Wilson et al., 2015; Alpert et al., 2011). In this study, we found that the fraction of submicron gels $(0.4-1 \mu \mathrm{m})$ in the SML increased at high wind speeds $\left(>6 \mathrm{~m} \mathrm{~s}^{-1}\right)$ after the addition of E. huxleyi and on day 11 with the peak concentration of bacterial abundance in the SML (Fig. 8). Due to the TEP's flexible nature, small gels can pass through a filter with a size of $0.4 \mu \mathrm{m}$ (Passow and Alldredge, 1995) and thus may escape the measurement. It is therefore likely that the fraction of submicron gels was even higher at high wind speeds than observed. The changes of size distribution of gel particles in the SML indicated that large gel particles were fragmented into smaller gels at high wind speed, or that submicron gels were generated. Strong enrichment of TEP in submicron SSA under field conditions has been observed by Aller et al. (2017). Production of SSA in the field is driven by wind speed, and SSAs in the size range $0.4-1 \mu \mathrm{m}$ in particular were observed to be higher at high wind speed (Lehahn et al., 2014). Therefore, our finding supported the results of Aller et al. (2017) and Lehahn et al. (2014) and suggest that the enhanced contribution of submicron gel particles at higher wind $>6 \mathrm{~m} \mathrm{~s}^{-1}$ after the addition of E. huxleyi, potentially impact the emission of gels with SSA.

In addition, pronounced changes through time in gel size slope and EFs were observed after the addition of E. huxleyi seed culture. At that time, shallower slopes for CSP and TEP revealed a higher abundance of larger gel particles relative to smaller ones for both SML and bulk water. Gel particles produced by autotrophs may be more surface active and more prone to aggregation (Zhou et al., 1998). The larger particle combined with the ballast effect of E. huxleyi more easily 


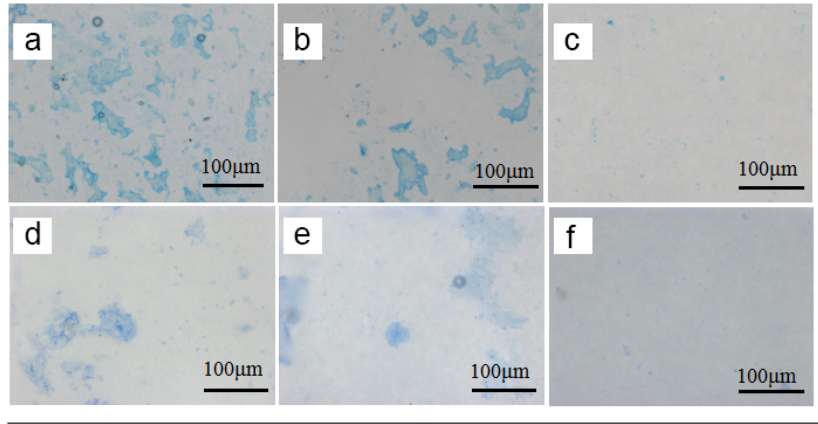

(g)

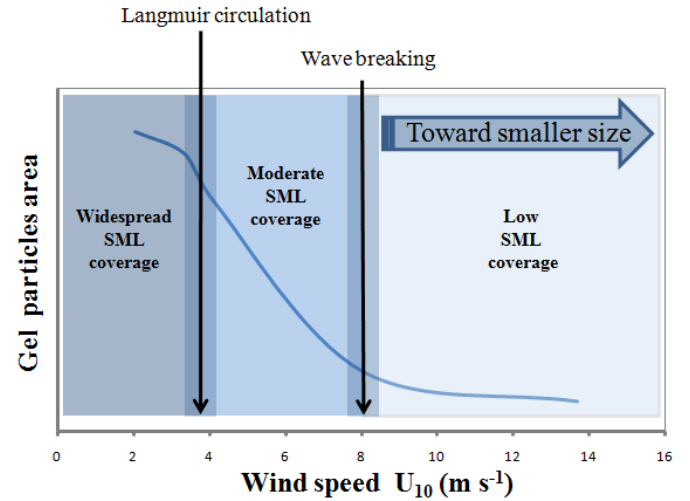

Figure 8. Strong accumulation of TEP and CSP in the SML at low wind speed as determined by microscopy, (a) TEP $\left(2.0 \mathrm{~m} \mathrm{~s}^{-1}\right)$, (b) TEP $\left(4.3 \mathrm{~m} \mathrm{~s}^{-1}\right)$, (c) TEP $\left(8.3 \mathrm{~m} \mathrm{~s}^{-1}\right)$, (d) CSP $\left(2.0 \mathrm{~m} \mathrm{~s}^{-1}\right)$, (e) CSP $\left(4.3 \mathrm{~m} \mathrm{~s}^{-1}\right)$, (f) CSP $\left(8.3 \mathrm{~m} \mathrm{~s}^{-1}\right)$; (g) proposed schematic for interactions between wind speed and gel particle coverage in the SML.

sink out of the SML. This, to a certain extent, may explain that a decrease in the EFs of CSP and TEP after the addition of the E. huxleyi seed. The observed changes after addition of the E. huxleyi seed culture indicates that variations in gel particles in the SML may also depend on the source of gels and gel precursors.

\section{Conclusion}

Our study showed that an enrichment of biogenic gel particles in the SML can occur at a low speed $\left(<6 \mathrm{~m} \mathrm{~s}^{-1}\right)$ despite low autotrophic productivity in the water column. A negative exponential relationship between the total area of gel particles in the SML and wind speed was observed in most cases. Our results showed that the PSD is an important parameter for characterizing the shape of the gel particle size distribution in the SML and reflects the particles' fate in the SML (i.e., aggregation, fragmentation and injection into air). The slope of PSD for $\operatorname{TEP}_{(2-16 \mu \mathrm{m})}$ and the maximum size of gel particles in the SML varied significantly at about $8 \mathrm{~ms}^{-1}$. The influence of wind speed on spectral slopes is more pronounced for $\mathrm{TEP}_{\mathrm{SML}}$ than for $\mathrm{CSP}_{\mathrm{SML}}$, and $\mathrm{CSP}_{\mathrm{SML}}$ are less prone to aggregation than $\mathrm{TEP}_{\mathrm{SML}}$ during the low wind speed. The enhancement of contribution of submicron gel particles in the SML at higher wind $\left(>6 \mathrm{~m} \mathrm{~s}^{-1}\right)$ after the addition of $E$. huxleyi indicates that biological activity may potentially influence the emission of gels with sea spray aerosol. Overall, variations in gel particle sizes in the SML can provide useful information on particle dynamics at the interface between air and sea.

To better understand the role of biogenic gel particles for bio-physicochemical processes across the air-sea interface, future studies should consider the full size spectrum of gels scaling from nanometers to micrometers and also include their chemical composition. This could provide important information on implications of marine gels for aerosol and cloud formation as well as for air-sea gas exchange.

Data availability. All data are available at https://doi.org/10.1594/PANGAEA.891025 (Sun et al., 2018).

Supplement. The supplement related to this article is available online at: https://doi.org/10.5194/bg-15-3577-2018-supplement.

Competing interests. The authors declare that they have no conflict of interest.

Acknowledgements. We thank Tania Klüver, Ruth Flerus, Katja Laß, Sonja Endres and Jon Roa for technical assistance. Armin Form helped to collect seawater for the Aeolotron experiment onboard the RV Poseidon. This study was supported by the SOPRAN-III project $(03 \mathrm{~F} 06622.2)$ and by the China Scholarship Council (grant number 201408440016). We also thank Bernd Jähne, Kerstin Krall and Maximilian Bopp for providing access and support during the Aeolotron experiment, and for sharing their data and knowledge. This study is a contribution to the international Surface Ocean Lower Atmosphere Study (SOLAS).

Edited by: Gerhard Herndl

Reviewed by: two anonymous referees

\section{References}

Alldredge, A. L., Passow, U., and Logan, B. E.: The Abundance and Significance of a Class of Large, Transparent Organic Particles in the Ocean, Deep-Sea Res. Pt. I, 40, 1131-1140, https://doi.org/10.1016/0967-0637(93)90129-Q, 1993.

Aller, J. Y., Radway, J. C., Kilthau, W. P., Bothe, D. W., Wilson, T. W., Vaillancourt, R. D., Quinn, P. K., Coffman, D J., Murray, B. J., and Knopf, D. A.: Size-resolved characterization of the polysaccharidic and proteinaceous components of sea spray aerosol, Atmos. Environ., 154, 331-347, https://doi.org/10.1016/j.atmosenv.2017.01.053, 2017.

Alpert, P. A., Aller, J. Y., and Knopf, D. A.: Initiation of the ice phase by marine biogenic surfaces in supersaturated gas and 
supercooled aqueous phases, Phys. Chem. Chem. Phys., 13, 19882-19894, https://doi.org/10.1039/c1cp21844a, 2011.

Azetsu-Scott, K. and Niven, S. E. H.: The role of transparent exopolymer particles (TEP) in the transport of Th-234 in coastal water during a spring bloom, Cont. Shelf Res., 25, 1133-1141, https://doi.org/10.1016/j.csr.2004.12.013, 2005.

Belcher, S. E., Grant, A. L. M., Hanley, K. E., Fox-Kemper, B., Van Roekel, L., Sullivan, P. P., Large, W. G., Brown, A., Hines, A., Calvert, D., Rutgersson, A., Pettersson, H., Bidlot, J. R., Janssen, P. A. E. M., and Polton, J. A.: A global perspective on Langmuir turbulence in the ocean surface boundary layer, Geophys. Res. Lett., 39, L18605, https://doi.org/10.1029/2012gl052932, 2012.

Calleja, M. Ll., Duarte, C. M., Prairie, Y. T., Agustí, S., and Herndl, G. J.: Evidence for surface organic matter modulation of air-sea $\mathrm{CO}_{2}$ gas exchange, Biogeosciences, 6, 1105-1114, https://doi.org/10.5194/bg-6-1105-2009, 2009.

Carlson, D. J.: Dissolved Organic Materials in Surface Microlayers - Temporal and Spatial Variability and Relation to Sea State, Limnol. Oceanogr., 28, 415-431, https://doi.org/10.4319/lo.1983.28.3.0415, 1983.

Cunliffe, M., Engel, A., Frka, S., Gasparovic, B., Guitart, C., Murrell, J. C., Salter, M., Stolle, C., Upstill-Goddard, R., and Wurl, O.: Sea surface microlayers: A unified physicochemical and biological perspective of the air-ocean interface, Prog. Oceanogr., 109, 104-116, https://doi.org/10.1016/j.pocean.2012.08.004, 2013.

Donelan, M. A.: Air-Water Exchange Processes, in: Physical Pro cesses in Lakes and Oceans, American Geophysical Union, Washington, 19-36, 1998.

Ebling, A. M. and Landing, W. M.: Sampling and analysis of the sea surface microlayer for dissolved and particulate trace elements, Mar. Chem., 177, 134-142, https://doi.org/10.1016/j.marchem.2015.03.012, 2015.

Ellis, K. M., Bowers, D. G., and Jones, S. E.: A study of the temporal variability in particle size in a high energy regime, Coast. Shelf Sci., 61, 311-315, https://doi.org/10.1016/j.ecss.2004.06.001, 2004.

Engel, A.: Determination of marine gel particles. Practical Guidelines for the Analysis of Seawater, CRC Press, Boca Raton, 2009.

Engel, A. and Galgani, L.: The organic sea-surface microlayer in the upwelling region off the coast of Peru and potential implications for air-sea exchange processes, Biogeosciences, 13, 989-1007, https://doi.org/10.5194/bg-13-989-2016, 2016

Engel, A., Thoms, S., Riebesell, U., Rochelle-Newall, E., and Zondervan, I.: Polysaccharide aggregation as a potential sink of marine dissolved organic carbon, Nature, 428, 929-932, https://doi.org/10.1038/nature02453, 2004.

Engel, A., Sperling, M., Sun, C. C., Grosse, J., and Friedrichs, G.: Bacterial control of organic matter in the surface microlayer: Insights from a wind wave channel experiment, Frontiers in Marine Sciences, 5, 182, https://doi.org/10.3389/fmars.2018.00182, 2018.

Falkowska, L.: A field evaluation of teflon plate, glass plate and screen sampling techniques. Part 1. Thickness of microlayer samples and relation to wind speed, Oceanol., 41, 211-221, 1999.

Frew, N. M., Bock, E. J., Schimpf, U., Hara, T., Haussecker, H., Edson, J. B., McGillis, W. R., Nelson, R. K., McKenna, S. P., Uz, B. M., and Jahne, B.: Air-sea gas trans- fer: Its dependence on wind stress, small-scale roughness, and surface films, J. Geophys. Res.-Oceans, 109, C08S17, https://doi.org/10.1029/2003JC002131, 2004.

Gantt, B., Meskhidze, N., Facchini, M. C., Rinaldi, M., Ceburnis, D., and O'Dowd, C. D.: Wind speed dependent size-resolved parameterization for the organic mass fraction of sea spray aerosol, Atmos. Chem. Phys., 11, 8777-8790, https://doi.org/10.5194/acp-11-8777-2011, 2011.

Garrett, W. D. and Duce, R. A.: Surface Microlayer Samplers, in: Air-Sea Interaction: Instruments and Methods, edited by: Dobson, F., Hasse, L., and Davis, R., Springer US, Boston, MA, 471490, 1980.

GESAMP: The Sea-Surface Microlayer and its Role in Global Change, Reports and Studies, WMO, 1995.

Graham, D. E. and Phillips, M. C.: Proteins at liquid interfaces: I. Kinetics of adsorption and surface denaturation, J. Colloid Interf. Sci., 70, 403-414, https://doi.org/10.1016/0021-9797(79)90048$1,1979$.

Guasco, T. L., Cuadra-Rodriguez, L. A., Pedler, B. E., Ault, A. P., Collins, D. B., Zhao, D. F., Kim, M. J., Ruppel, M. J., Wilson, S. C., Pomeroy, R. S., Grassian, V. H., Azam, F., Bertram, T. H., and Prather, K. A.: Transition Metal Associations with Primary Biological Particles in Sea Spray Aerosol Generated in a Wave Channel, Environ. Sci. Technol., 48, 1324-1333, https://doi.org/10.1021/es403203d, 2014.

Knopf, D. A., Alpert, P. A., Wang, B., and Aller, J. Y.: Stimulation of ice nucleation by marine diatoms, Nat. Geosci., 4, 88-90, https://doi.org/10.1038/ngeo1037, 2011.

Kuznetsova, M., Lee, C., and Aller, J.: Characterization of the proteinaceous matter in marine aerosols, Mar. Chem., 96, 359-377, https://doi.org/10.1016/j.marchem.2005.03.007, 2005.

Leck, C. and Bigg, E. K.: Source and evolution of the marine aerosol - A new perspective, Geophys. Res. Lett., 32, L19803, https://doi.org/10.1029/2005GL023651, 2005.

Lehahn, Y., Koren, I., Rudich, Y., Bidle, K. D., Trainic, M., Flores, J. M., Sharoni, S., and Vardi, A.: Decoupling atmospheric and oceanic factors affecting aerosol loading over a cluster of mesoscale North Atlantic eddies, Geophys. Res. Lett., 41, 40754081, https://doi.org/10.1002/2014GL059738, 2014.

Liss, P. S. A. D. R. A.: The Sea Surface and Global Change, Cambridge University Press, Cambridge, 2005.

Liu, K. W. and Dickhut, R. M.: Effects of wind speed and particulate matter source on surface microlayer characteristics and enrichment of organic matter in southern Chesapeake Bay, J. Geophys. Res.-Atmos., 103, 10571-10577, https://doi.org/10.1029/97jd03736, 1998.

Long, R. A. and Azam, F.: Abundant protein-containing particles in the sea, Aquat. Microb. Ecol., 10, 213-221, https://doi.org/10.3354/Ame010213, 1996.

Mari, X. and Kiorboe, T.: Abundance, size distribution and bacterial colonization of transparent exopolymeric particles (TEP) during spring in the Kattegat, J. Plankton Res., 18, 969-986, https://doi.org/10.1093/plankt/18.6.969, 1996.

Mari, X. and Robert, M.: Metal induced variations of TEP sticking properties in the southwestern lagoon of New Caledonia, Mar. Chem., 110, 98-108, https://doi.org/10.1016/j.marchem.2008.02.012, 2008.

Mari, X., Passow, U., Migon, C., Burd, A. B., and Legendre, L.: Transparent exopolymer particles: Effects on car- 
bon cycling in the ocean, Prog. Oceanogr., 151, 13-37, https://doi.org/10.1016/j.pocean.2016.11.002, 2017.

McCave, I. N.: Size Spectra and Aggregation of Suspended Particles in the Deep Ocean, Deep-Sea Res., 31, 329-352, https://doi.org/10.1016/0198-0149(84)90088-8, 1984.

Melville, W. K.: The role of surface-wave breaking in the air-sea interaction, Annu. Rev. Fluid Mech., 28, 279-321, https://doi.org/10.1146/annurev.fl.28.010196.001431, 1996.

Mesarchaki, E., Kräuter, C., Krall, K. E., Bopp, M., Helleis, F., Williams, J., and Jähne, B.: Measuring air-sea gas-exchange velocities in a large-scale annular wind-wave tank, Ocean Sci., 11, 121-138, https://doi.org/10.5194/os-11-121-2015, 2015.

Nagel, L., Krall, K. E., and Jähne, B.: Comparative heat and gas exchange measurements in the Heidelberg Aeolotron, a large annular wind-wave tank, Ocean Sci., 11, 111-120, https://doi.org/10.5194/os-11-111-2015, 2015.

Orellana, M. V., Matrai, P. A., Leck, C., Rauschenberg, C. D., Lee, A. M., and Coz, E.: Marine microgels as a source of cloud condensation nuclei in the high Arctic, P. Natl. Acad. Sci. USA, 108, 13612-13617, https://doi.org/10.1073/pnas.1102457108, 2011.

Passow, U.: Transparent exopolymer particles (TEP) in aquatic environments, Prog. Oceanogr., 55, 287-333, https://doi.org/10.1016/S0079-6611(02)00138-6, 2002.

Passow, U. and Alldredge, A. L.: Aggregation of a Diatom Bloom in a Mesocosm - the Role of Transparent Exopolymer Particles (Tep), Deep-Sea Res. Pt. II, 42, 99-109, https://doi.org/10.1016/0967-0645(95)00006-C, 1995.

Prieto, L., Ruiz, J., Echevarria, F., Garcia, C. M., Bartual, A., Galvez, J. A., Corzo, A., and Macias, D.: Scales and processes in the aggregation of diatom blooms: high time resolution and wide size range records in a mesocosm study, Deep-Sea Res. Pt. I, 49, 1233-1253, https://doi.org/10.1016/S0967-0637(02)000249, 2002.

Romano, J. C.: Sea-surface slick occurrence in the open sea (Mediterranean, Red Sea, Indian Ocean) in relation to wind speed, Deep-Sea Res. Pt. I, 43, 411-423, https://doi.org/10.1016/0967-0637(96)00024-6, 1996.

Ruiz, J. E. and Izquierdo, A.: A simple model for the break-up of marine aggregates by turbulent shear, Oceanolica Acta, 20, 597605, 1997.

Russell, L. M., Hawkins, L. N., Frossard, A. A., Quinn, P. K., and Bates, T. S.: Carbohydrate-like composition of submicron atmospheric particles and their production from ocean bubble bursting, P. Natl. Acad. Sci. USA, 107, 6652-6657, https://doi.org/10.1073/pnas.0908905107, 2010.
Stoderegger, K. E. and Herndl, G. J.: Production of exopolymer particles by marine bacterioplankton under contrasting turbulence conditions, Mar. Ecol. Prog. Ser., 189, 9-16, 1999.

Sun, C.-C., Sperling, M., and Engel, A.: Effect of wind speed on the size distribution of gel particles in the sea surface microlayer: Insights from a wind wave channel experiment, PANGAEA, https://doi.org/10.1594/PANGAEA.891025, 2018.

UNESCO: Procedure for sampling the sea surface microlaye, in: IOC Manuals and Guide 15, UNESCO (United Nations Educational, Scientific and Cultural organization), Paris, 1985.

Van Vleet, E. S. and Williams, P. M.: Surface potential and film pressure measurements in seawater systems, Limnol. Oceanogr. 28, 401-414, https://doi.org/10.4319/lo.1983.28.3.0401, 1983.

Wilson, T. W., Ladino, L. A., Alpert, P. A., Breckels, M. N., Brooks, I. M., Browse, J., Burrows, S. M., Carslaw, K. S., Huffman, J. A., Judd, C., Kilthau, W. P., Mason, R. H., McFiggans, G., Miller, L. A., Najera, J. J., Polishchuk, E., Rae, S., Schiller, C. L., Si, M., Temprado, J. V., Whale, T. F., Wong, J. P. S., Wurl, O., Yakobi-Hancock, J. D., Abbatt, J. P. D., Aller, J. Y., Bertram, A. K., Knopf, D. A., and Murray, B. J.: A marine biogenic source of atmospheric ice-nucleating particles, Nature, 525, 234, https://doi.org/10.1038/nature14986, 2015.

Wurl, O. and Holmes, M.: The gelatinous nature of the sea-surface microlayer, Mar. Chem., 110, 89-97, https://doi.org/10.1016/j.marchem.2008.02.009, 2008.

Wurl, O., Miller, L., Ruttgers, R., and Vagle, S.: The distribution and fate of surface-active substances in the seasurface microlayer and water column, Mar. Chem., 115, 1-9, https://doi.org/10.1016/j.marchem.2009.04.007, 2009.

Wurl, O., Miller, L., and Vagle, S.: Production and fate of transparent exopolymer particles in the ocean, J. Geophys. Res.-Oceans, 116, C00H13, https://doi.org/10.1029/2011JC007342, 2011.

Wurl, O., Stolle, C., Van Thuoc, C., The Thu, P., and Mari, X.: Biofilm-like properties of the sea surface and predicted effects on air-sea $\mathrm{CO}_{2}$ exchange, Prog. Oceanogr., 144, 15-24, https://doi.org/10.1016/j.pocean.2016.03.002, 2016.

Zhou, J., Mopper, K., and Passow, U.: The role of surface-active carbohydrates in the formation of transparent exopolymer particles by bubble adsorption of seawater, Limnol. Oceanogr., 43, 1860-1871, https://doi.org/10.4319/lo.1998.43.8.1860, 1998. 